\title{
Piracy Influence ON THE SHIPOWNERS AND INSURANCE COMPANIES
}

\author{
BENDEKOVIC, J. \& VULETIC, D.
}

Abstract: Piracy is growing international problem which has strong influence on the shipowners, insurance companies, economic activities of neighbouring countries, whole shipping industry and finally on the whole world economy. Seriousness of the problem is recognized by International Maritime Organisation and many states which are issuing new regulations to enable employment of the armed guards and possibility of armed crew to the shipowners. As a consequence of pirate attacks the shipowners are confronted with the increasing costs. In the paper are defined the direct and secondary costs of piracy for the shipowners. On the other side piracy has strong impact on the maritime insurance industry. In last years insurance premiums for the risk areas are rapidly increasing. In the near future one should be improve the politic and economic situation in Somalia as it is the only way to combat piracy and its intense impact on the maritime industry, consequently whole global economy.

Key words: piracy, insurance, shipowners, War risk, Kidnap \& Ransom risk
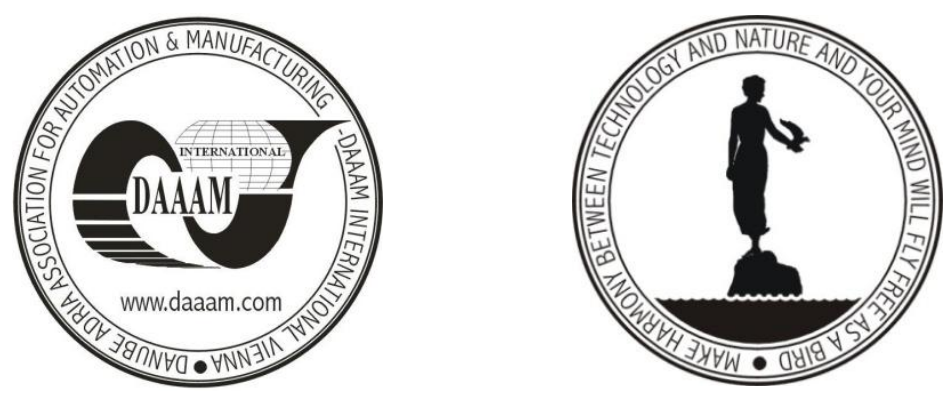

Authors' data: Univ.Prof. Dr.sc. Bendekovic, J[adranka]; Vuletic, D[ora], Faculty of Economics \& Business, J. F. Kennedy 6, 10000, Zagreb, Croatia, jadranka.bendekovic@efzg.hr, dora.vuletic@efzg.hr

This Publication has to be referred as: Bendekovic, J[adranka] \& Vuletic, D[ora] (2013) Piracy Influence on the Shipowners and Insurance Companies, Chapter 42 in DAAAM International Scientific Book 2013, pp. 711-718, B. Katalinic \& Z. Tekic (Eds.), Published by DAAAM International, ISBN 978-3-901509-94-0, ISSN 17269687, Vienna, Austria

DOI: $10.2507 /$ daaam.scibook.2013.42 
Bendekovic, J. \& Vuletic, D.: Piracy Influence on the Shipowners and Insuran...

\section{Introduction}

Piracy is growing international problem which reflects on shipowners, insurance companies, economic activities of neighbouring countries, whole shipping industry and finally on the whole world economy.

Piracy consists of any of the following acts:

(a) any illegal acts of violence or detention, or any act of depredation, committed for private ends by the crew or the passengers of a private ship or a private aircraft, and directed:

(i) on the high seas, against another ship or aircraft, or against persons or property on bord of such ship or aircraft;

(ii) against a ship, aircraft, persons or property in a place outside the jurisdiction of any State;

(b) any act of voluntary participation in the operation of a ship or of an aircraft with knowledge of facts making it a pirate ship or aircraft;

(c) any act of inciting or of intentionally facilitating an act described in subparagraph (a) or (b) (United Nations Convention On The Law of The Sea of 10 December 1982).

More than $80 \%$ of world economy is carried out through maritime ways and that reflects the importance of maritime traffic. At the beginning of the 90' years of the last century international community has unexpectedly faced with the appearance of the modern piracy. Ten years ago has started culmination of pirate attacks near the Somalia coast, Gulf of Aden and Indian ocean. The main characteristic of the modern piracy is that it is usually carried out on the frequent maritime routes and that is not directed to breach interests of some particular country, it is oriented to all ships equally regardless of their territorial affiliation (Pospisil, 2012).

Pirate attacks have strong negative effects on the whole global economy, specially for the maritime economy and the global peace. International Maritime Organisation (IMO) is working on the pirate suppression for more than 30 years. United Nations Security Council has also recognized the seriousness of this problem and in 2008 has adopted Resolution 1814, Resolution 1816 and Resolution 1851 which are defining strategies for the greater international presence in east African country and it regulate operations in Somalia (http://www.un.org/docs/ sc/unsc_resolutions08.htm).

There is a lot of supporting organisations that are involved in development of protections against piracy and the major are following: The Baltic and International Maritime Council (BIMCO), International Chamber of Shipping (ICS), The International Group of P\&I Clubs (IGP\&I), ICC International Maritime Bureau (IMB) and International Transport Workers Federation (ITF) (www.warrisk.no). It is encouraging that number of States, issuing new regulations to enable to the shipowners employment of the armed guards and possibility of armed crew, is increasing (Pospisil, 2012). 


\section{Piracy Statistics}

Maritime piracy is as old as seaborne trade but piracy attacks have dramatically raised after 2000. The main factors that have influenced on the increased number of piracy attacks are:

-the enormous and raising volume of commercial freight that moves by sea, -the selected ship routes that need to be followed to pass through high risk sea areas,

-the willingness of the shipowners to pay large sums of money to get their ships back (Sakellaridou, 2009).

\begin{tabular}{|c|c|c|c|c|c|c|c|c|}
\hline & $005^{2}$ & $006^{2}$ & $007^{2}$ & $008^{2}$ & $009^{2}$ & $010^{2}$ & $011^{2}$ & $012^{2}$ \\
\hline $\begin{array}{l}\text { South East } \\
\text { Asia }\end{array}$ & $02^{1}$ & $3^{8}$ & $0^{7}$ & $4^{5}$ & $6^{4}$ & $0^{7}$ & $0^{8}$ & $04^{1}$ \\
\hline Africa & $0^{8}$ & $1^{6}$ & $23^{1}$ & $89^{1}$ & $70^{2}$ & $59^{2}$ & $83^{2}$ & $50^{1}$ \\
\hline $\begin{array}{l}\text { Indian Sub- } \\
\text { Continent }\end{array}$ & $6^{3}$ & $3^{5}$ & $0^{3}$ & $3^{2}$ & $0^{3}$ & $8^{2}$ & $6^{1}$ & $9^{1}$ \\
\hline America & $5^{2}$ & $9^{2}$ & $1^{2}$ & $4^{1}$ & $7^{3}$ & $0^{4}$ & $5^{2}$ & $7^{1}$ \\
\hline Far East & $0^{2}$ & 5 & $0^{1}$ & $1^{1}$ & $3^{2}$ & $4^{4}$ & $3^{2}$ & 7 \\
\hline $\begin{array}{l}\text { Rest of } \\
\text { World }\end{array}$ & & 8 & 9 & 2 & 4 & 4 & 2 & 0 \\
\hline TOTAL & $76^{2}$ & & $6^{2}$ & $93^{2}$ & $10^{4}$ & $45^{4}$ & & $97^{2}$ \\
\hline
\end{tabular}

Tab. 1. Piracy attacks by Region

Source: ICC International Maritime Bureau (2013) Piracy and Armed Robbery Against Ships - Annual Report 2012, pg. 5; Geopolicity (2011) The Economics of Piracy, pg. 17

In the table 1 it can be seen that pirate attacks on the world's sea have significant growth in 2009 and that it reached its peak of 445 attacks in 2010. Encouraging is that in 2012 number of attacks has significantly dropped and it was less for 32\% than the number of attacks in the 2011. In Somalia and the Gulf of Aden, which is the most exposed area to piracy, it has been reported just 75 attacks in 2012 compared to 237 attacks in 2011. That significant downfall in Somalia is result of the increased number of naval ships deployed in that area in aim to obstruct piracy operations. But, pirates have started to use captured vessels and mother-ships that provide them to operate far from the home (www.igpandi.org). Motherships are more effective attack platforms than smaller skiffs and enable the pirate operations even when it is monsoon season (Kendall-Marsden, 2011). 
Bendekovic, J. \& Vuletic, D.: Piracy Influence on the Shipowners and Insuran...

Preparation of pirate attacks doesn't require enormous financial resources but expected profit is very high and because of it there is each day more inhabitants from those poor countries who are interested for this business. Most of pirates that are arrested from the military ships of individual countries are in the major number of cases released immediately as most of countries don't want to accept the trials to pirates as they fear that they could ask for the asylum (Odeke, 2011).

In the table 2 it can be seen that if observing pirate attacks by type of ship that at leading positions are bulk carriers and product, chemical tankers. That is expected as pirate prefers more to attack the vessels that are sailing at the lower speed.

\begin{tabular}{|c|c|c|c|c|c|}
\hline TYPE OF SHIP & $\mathbf{2 0 0 8}$ & $\mathbf{2 0 0 9}$ & $\mathbf{2 0 1 0}$ & $\mathbf{2 0 1 1}$ & $\mathbf{2 0 1 2}$ \\
\hline Bulk carrier & 48 & 109 & 80 & 100 & 66 \\
\hline $\begin{array}{c}\text { Tanker } \\
\text { (chemical/product) }\end{array}$ & 55 & 69 & 96 & 100 & 76 \\
\hline Container & 49 & 64 & 74 & 62 & 39 \\
\hline Tug & 16 & 17 & 20 & 32 & 23 \\
\hline General cargo & 38 & 54 & 63 & 35 & 15 \\
\hline LPG tanker & 6 & 5 & 7 & 6 & 10 \\
\hline Offshore supply ship & 5 & 1 & 0 & 1 & 8 \\
\hline Offshore tug & & & & & 6 \\
\hline
\end{tabular}

Tab. 2. Selected types of attacked ships from 2008-2012

Source: ICC International Maritime Bureau (2013) Piracy and Armed Robbery Against Ships- Annual Report 2012,pg. 13

The pirates have spread they reach more to the south as a reponse to increased naval patrol activity and interfence in the Gulf of Aden and Arabian Sea but also because of lower number of ships as many of them have changed their routes in aim to avoid the piracy-prone areas. Consequently there are three main risk areas on the East African coast: Kenya, Mozambique channel and Tanzania (Mathiesen, 2010). More than 22000 ships are passing through Gulf of Aden per year, what represents $8 \%$ of world's economy and $12 \%$ of total gas transport (Sosic, 2011).

\section{Costs for Shipowners}

Costs of Piracy could be separeted in 2 groups:

- Direct Economic Costs of Piracy and

- Secondary Costs of Piracy. 


\subsection{Direct Economic Costs}

Direct economic costs of piracy are following: the cost of ransoms, the cost of insurance, the cost of re-routing, the cost of deterrent security equipment, the cost of naval forces, the cost of piracy prosecutions and the cost of piracy-deterrence organizations. While direct costs are more focused on the piracy inluence on the shippingg industry and governments, secondary costs are oriented on the regional countries that are close to piracy areas.

\subsection{Secondary (macroeconomic) Costs}

Secondary cost are related to the: costs to regional trade, cost to food price inflation and cost of reduced foreign revenue (Bowden et al, 2010).

As a result of increasing number of piracy attacks there are new costs for the ship owners:

1. The Cost of Security Equipment and Private armed Security

2. The Cost of Re-Routing

3. The Cost of Increased Speed

4. The Cost to Labor

5. The Cost of Prosecutions \& Imprisonment

6. The Cost of Military Operations

7. The Cost of Counter-Piracy Organizations (Oceans Beyond Piracy, 2012).

In last years shipowners are trying to protect their ships from pirate attacks through security equipment and by employment of private armed security on their ships. The cost of those protection can reached 134000 USD per transit (Bowden et al, 2010).

At the beggining ransoms have been between few thousands USD on average, while today are more than 3 million USD. Longer stays of ships on their trips have influence on the loss of earnings, increase of insurance premiums and on many other costs (Pospisil, 2012).

Ship companies from South Africa are in the most unfavorable position as they have to bear with the higher transport costs and maritime insurance as a consequence of often pirate attacks in that area. In aim to protect more ships and crews against pirate attacks security equipment industry has developed a numerous technical solutions such as highly sensitive radar systems which can detect approaching pirates as close range, special night-vision equipment and visual alarm systems, high security containers to protect the cargo and acoustic defense system.

It is hard to define precisely the highness of the total costs of the piracy, but it is estimated, based on those defined direct and macroeconomic costs, that they are between 7 and 12 billions USD yearly. On the other side it is estimated that pirates are earning more than 100 million USD per year (Pospisil, 2012). 
Bendekovic, J. \& Vuletic, D.: Piracy Influence on the Shipowners and Insuran...

\begin{tabular}{|c|c|c|}
\hline COUNTRY & MAIN COST FACTOR & $\begin{array}{c}\text { LOSS PER YEAR } \\
\text { (in million USD) }\end{array}$ \\
\hline Egypt & loss of revenue from Suez Canal fees & 642 \\
\hline Kenya & trade impact & 414 \\
\hline Nigeria & losses to oil and fishing industries & 42 \\
\hline Seychelles & losses to fishing and tourism industries & 6 \\
\hline Yemen & trade impact & 150 \\
\hline TOTAL & & $\mathbf{1 . 2 5 0}$ \\
\hline
\end{tabular}

Tab. 3. Macroeconomic cost as a result of piracy in selected countries

Source: Bowden, A. et al (2011) The economic cost of maritime piracy, Seaways, London, United Kingdom, pg. 10

\section{Piracy Influence on Insurance Companies}

Shipping insurance comes in four main types:

- war risk (charge for a ships that are sailing in 'war risk area')

- kidnap and ransom risk (insurance for the crew),

- cargo risk (insurance for cargo that is transported by the ship ) and

- hull insurance (insurance for any physical damage of the ship) (Bowden et al, 2010).

Two primary forms of piracy-related insurance are War Risk and Kidnap and Ransom Risk. War Risk is the most appropriate form of insurance to cover against pirate attacks but there are also some benefits of protection under the K\&R Risk as that insurance typically protects the crew but without the vessel or hull (Oceans Beyond Piracy, 2012).

The clause named 'Preils Clause' that is used by the Institute Hull Clauses includes 'piracy' or precisely violent acts of presons who bord the vessel with an intention to steal. The losses related to the piracy primarily affect marine cargo, marine hull and protection and indemnity clubs (Sakellaridou, 2009).The protection and indemnity clubs have clearly defined that they do not cover ransom payments. Most of ships are insured against piracy under their war risks insurance. When piracy is included in the war risk insurance companies charge an additional premium if a ship trade in the pirate areas (www.igpandi.org).Increased number of piracy attacks on sea has strong influence on maritime insurance industry. As a result of increasing number of piracy attacks maritime insurance industry has increased its shipping rates and premiums, particulary those for high-risk piracy zones. How strong influence pirate attacks have on the insurance premiums is reflected in the fact that in 2008 insurance premiums for kidnap and ransom for the ships that are sailing through Gulf of Aden have increased by ten times as a result of significant growth of piracte attacks.

It is worrying that the influence on insurance premiums should be even bigger if all the pirate attacks have been reported. According to the International Maritime Organization the reasons for many of under-reported attacks are following: 
1. The subsequent increase in insurance premiums. This increase often outweighs the value of the claim for smaller attacks and

2. The time-consuming procedure of reporting a pirate attack could lead to significant delay. Considering the sunk costs of an idle ship, it is sometime cheaper not to report the attack (Sakellaridou, 2009).

\section{Conclusion}

As piracy is growing international problem which reflects on shipowners, insurance companies, economic activities of neighbouring countries, whole shipping industry and finally on the whole world economy. In this paper its influence on the shipowners and maritime insurance was analysed.

Pirate attacks have strong negative effects on the whole global economy, specially for the maritime economy and the global peace. International Maritime Organisation is working on the pirate suppression for more than 30 years. The number of supporting organisations that are involved in development of protections against piracy and the States that have recognized seriousness of the piracy is increasing. Maritime piracy is old as seaborne trade but piracy attacks have dramatically raised after 2000. Preparation of pirate attacks doesn't require enermous financial resources but expected profit is very high and because of it there is each day more inhabitants from those poor countries who are interested in this business. Most of pirates that are arrested by the military ships of individual countries are in most of cases released immediately as most of countries don't want to accept the trials to pirates as they fear that they could ask for the asylum.

In the last years shipowners are trying to protect their ships from pirate attacks through security equipment and by employment of private armed security on their ships. Longer stays of ships on their trips have influence on the loss of earnings, increase of insurance premiums and on many other costs. Consequence of the increased number of pirate attacks is that shipowners are faced with the new costs: the cost of security, equipment and private armed security, the cost of re-routing, the cost of increased speed, the cost to labor, the cost of prosecutions \& imprisonment, the cost of military operations and the cost of counter-piracy organizations. Ship companies from South Africa are in the most unfavorable position as they have to bear the higher transport costs and maritime insurance as a consequence of often pirate attacks in that area. It is estimated that total cost of piracy are between 7 and 12 billions USD per year. Increased number of piracy attacks on sea has strong influence on maritime insurance industry. As a result of increasing number of piracy attacks maritime insurance industry has increased its shipping rates and premiums, particulary those for high-risk piracy zones. In the near future politic and economic situation in the Somalia should be improved as it is the only way to combat piracy and its intense impact on the maritime industry, consequently whole global economy.

Previous research have mostly been oriented on the area of the Somalia and on analysis of the economic costs and strategies of the pirates. It should be observed the influence of piracy on the neighbouring countries and on the development of measures that could stop further growth of piracy. It should be also analysed the connection between implemented measures against pirate attacks in Somalia and spread of the pirate attacks on the other areas. 
Bendekovic, J. \& Vuletic, D.: Piracy Influence on the Shipowners and Insuran...

\section{References}

Bowden, A. et al (2010). The Economic Costs of Maritime Piracy, Available from: http://oceansbeyondpiracy.org/sites/default/files/documents_old/The_Economic_Cost _of_Piracy_Full_Report.pdf Accessed: 2013-08-24

Kendall-Marsden, S. (2011). Piracy special edition. Available from: http://www.standard-

club.com/docs/StandardBulletinPiracySpecialEditionSeptember2011V2.pdf

Accessed: 2013-08-25

ICC International Maritime Bureau (2013) Piracy and Armed Robbery Against Ships - Annual Report 2012, Available from: http://drg.blob.core.windows.net/hellenicshippingnewsbody/pdf/Diafora/2012 Annual IMB Piracy Report ABRIDGED.pdf Accessed: 2013-09-13

Mathiesen, N. (2010). East Africa piracy update: A new trend. Available from: $\mathrm{http} / / / \mathrm{www}$. strategicinsights.eu/dyn/files/news_news/8-

file1/Strategic\%20Insights\%20No28.pdf Accessed: 2013-09-05

Odeke, A. (2011). Somali Piracy - Effects on Oceanborne Commerce and Regional Security and Challenges to International Law and World Order. Australian \& New Zeleand Maritime Law Journal, Vol. 25, No. 1, ISSN: 1834-0881

Pospisil, M. (2012). Somali piracy - from international naval operations to armament of merchant ships, Zbornik radova Pravnog fakulteta u Splitu, Bacic, A., pp. 59-66, Vol. 49, No. 1-2, ISSN 1847-0459, Split

Sakellaridou, S. (2009). Maritime Insurance \& Piracy, Available from: http://www.aida.org.uk/AIDAEurop/AIDAStellaspaper.pdf, Accessed: 2013-09-09

Sosic, I. Somali pirates-the Growing International Problem Which Needs to be Resolved Urgently. Nase more, No. 1-2, (June 2011) 82-89, ISSN: 0469-6255

United Nations Convention On The Law of The Sea of 10 December 1982, Part VII. High Seas, Article 101, 2013-08-18, Available from: http://www.un.org/Depts/los/convention_agreements/texts/unclos/closindx.htm *** http://www.geopolicity.com/upload/content/pub_1305229189_regular.pdf Geopolicity, The Economics of Piracy, Pirate Ransoms and Livelihoods off the Coast of Somalia (2011), Accessed: 2013-09-04

***http://www.igpandi.org/downloadables/piracy/news/Marsh\%20Piracy\%20implica tions.pdf - MARSH, Piracy- the insurance implications (2011), Accessed: 2013-0902

***http://oceansbeyondpiracy.org/sites/default/files/economic_cost_of_piracy_2011. pdf - Oceans Beyond Piracy, The Economic Cost of Somali Piracy 2011 (2012), Accessed: 2013-08-30

*** https://www.warrisk.no/filestore/Intranett_diverse/BMP4-17.08.11.pdf - Den Norske Krigsforsikring for Skib, Best Management Practices for Protection against Somalia Based Piracy (2011), Witherby Publishing Group Ltd, pg. 72-85, ISBN: 978 185609505 1, August 2011 